\title{
Technical and Lifetime Cost Benefit Analysis of RET Solar Water Heater a Way to Substitute Electrical Water Heaters for Domestic use:
}

\author{
A Case Study in Addis Ababa-Ethiopia
}

\author{
Tamerat Demeke Agonafer \\ Faculty of Mechanical and Industrial Engineering \\ Bahir Dar Institute of Technology, Bahir Dar University \\ Bahir Dar, Ethiopia
}

\begin{abstract}
The case study presents a lifetime cost benefit analysis for RET evacuated tube SWH comparing with EWH for domestic hot water production. The study is important to show the SWH technology is competitive, strengthen local electric use capacity and to stimulate acceptance of the solar technology in Ethiopia. To accomplish the study, conduct thermal performance test of imported RET evacuated tube SWH in order to see the feasibility with current condition of Addis Ababa. And analyze lifetime cost benefit of proposed RET Evacuated tube SWH and compare with commonly used EWH to show technical and economic advantages. In Addis Ababa, home builders and commercial sectors has alternatives of installing SWH and purchase EWH. However, from technical comparison study SWH has an advantage of improve energy security and risk management; reduce the use of electricity; reduce the GHG emissions; improve the quality of life through renewable energy; less payback period over EWH. Similarly, the breakeven analysis confirms that the life cycle save is about 1414.06 ETB and 943.36 ETB per year from electricity bill without considering maintenance and other exploitations, and SWH is profitable less than 6 and 14 years by installing SWH rather than using electrical storage type boiler and instant water heater respectively. In the long run, home builders are both technically and economically beneficial to install SWH.
\end{abstract}

Keywords- Electrical Storage Boiler, Engineering Economics, Evacuated Tube, Instant Water Heater, Solar Water Heater.

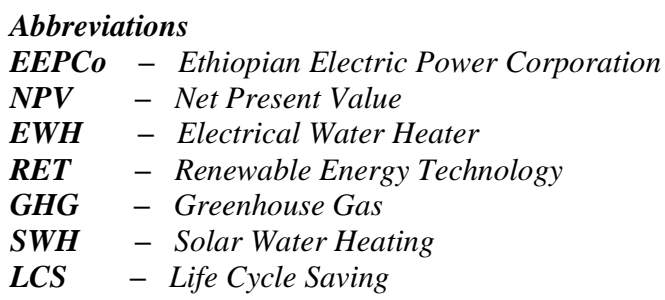

\section{INTRODUCTION}

The demand for electricity is growing rapidly throughout the world. Electricity is a popular energy source, it is useful for a variety of applications such as water heating, lighting, refrigeration etc., enormous amounts of capital investment required in its generation, transmission and distribution. Electricity consumption in the residential sector is also growing, because consumers enforced to use appliances which consume a large amount of electricity, due to this the energy

\author{
Abdulbasit Nasir Jemal \\ Department of Mechanical Engineering \\ Hawassa University \\ Hawassa, Ethiopia
}

demand management directed towards replacing appliances which consume large amounts of electricity with those which use renewable energy sources. We can consider solar energy as a plenty of alternative, especially where hot water required for domestic use, temperature from $30-70{ }^{\circ} \mathrm{C}$ [1]. Ethiopia, like other developing countries, faces the dual challenge of pursuing economic growth and environmental protection. Sustainable and renewable energy resources, offer an opportunity to meet both challenges.

Solar water heaters are a recent innovative technology, which not replace directly boilers for high temperature water apparatus in industrial application however, it might be used as preheating purpose. Solar water heater is suitable to produce domestic hot water based on a common Thermosyphon phenomenon. The system has contained an evacuated tube absorber, storage tank, circulation system and proper controlling and accessories (see Fig. 1). These are broadly two types of water heating system, Thermosyphon and natural circulation system (applications capacity $<300 \mathrm{~L}$ ) and forced circulation system (applications capacity > $300 \mathrm{~L}$ ) [2]. An extensive range of solar water heating technologies are available depending on the climatic and personal economic conditions. Solar water heating system is one of the most interesting technological devices, the simplest and the most largely widespread of solar energy exploitation. Its remarkable effectiveness coupled with the simplicity in its design, autonomy of operation, less maintenance required makes it an interesting alternative to the system using an electric power.

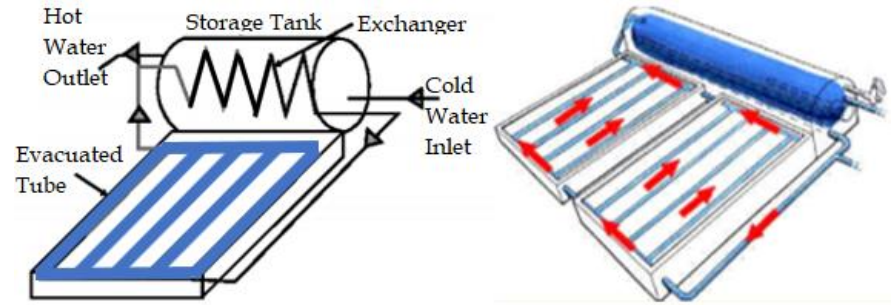

Figure 1. Solar Water Heater (SWH) Schematic Diagram.

A large number of experiments where conducted around the world to predict Thermosyphon solar water heater (SWH) performance. The studies show a difference in performance due to different designs, manufacturing materials, efficiency, expected lifetime etc. In spite of the fact that Ethiopia weather 
conditions experiences the tropical weather condition it is are suitable for the use of SWH installation. For this reason, companies established to import the technology and deliver to the end user. This article with current condition aims to outline first conduct the thermal performance test of imported RET SWH to proof the feasibility using evacuated tube SWH and compare with already available EWH to inspire the wide use of SWH in the Addis Ababa City. The second objective of the study presents lifetime cost benefit analysis for RET SWH comparing with commonly used EWH (storage type and instant water heaters) to show its economic feasibility for domestic use and indicate factors affecting the end user choice. Finally, the case study will discuss about the situation where how the initial cots probably influence the choice to use SWH and thus, it is useful to guide the customer about the lifetime cost saving economic advantages of both systems before they made a decision for utilities choice. To accomplish the study installed RET SWH performance data has been measured and collect necessary data for both systems directly from the supplier and from the market for economic and technical comparisons

\section{BACKGROUND AND DATA INFORMATION}

Solar water heaters in general classified as either active or passive and direct or indirect systems. They may make use of either flat plate collectors or evacuated tubes. Active solar water heaters use a pump to circulate the water between the collector and the storage tank, but passive solar water heater uses natural convection (Thermosiphon) to circulate the water between the collector and the storage tank. In direct solar water heater, the collector heats the water directly and the water then circulates between the collector and the storage tank. In indirect solar water heater, the water stored in the storage tank, and is heated by a heat transfer fluid. This is heated in the collector and flows around a jacket which surrounds the tank and thereby heats the water. An indirect system can be used in all conditions.

\section{A. Literatures on Solar Water Heating Technology}

Commercially solar water heater was patented in 1891 for the first time by William Bailey and installed solar hot water system about $30 \%$ of home builders in California, then the hot water heating industry has spread to part of USA by the 1930s. The working of solar water heater was a metal tank that was painted black and placed on the roof and tilted toward the sun. it worked, but usually took all day for the water to heat, then, as the sun get off, the system cooled quickly because of lack of insulation. This time investment requires about $\$ 25$, and people could save about $\$ 9$ a year in coal costs. Florida company (HM Carruthers) in 1923 purchased the patents and the solar hot water industry began in the coastal cities of central Florida and southern Florida in vast [3].

Laborderie et al [4] presented methodology for a life cycle assessment of solar water heater environmental evaluation. They focused on primary energy consumption, potential global warming, effect on ecosystem quality and human health issues. Environmental performances of the different SWH with gas-backup, electrical-backup or no backup are compared with standard hot water systems.

A detailed review and analysis in order to improve the performance of solar water heating are presented by
Yesuratnam [5]. The study described the design on the development of various system components that includes the collector, storage tank and heat exchanger.

Ayompe and Duffy [6] analyzed the thermal performance of a solar water heating system with evacuated tube collector of $3 \mathrm{~m} 2$ total area using climate data for Dublin in Ireland. The measurement indicates maximum collector outlet temperature was $70.3^{\circ} \mathrm{C}$ while the water temperature at the bottom of the hot water tank was $59.5^{\circ} \mathrm{C}$, annual average solar fraction was $33.8 \%$ and collector efficiency $63.2 \%$, the system efficiency was $52.0 \%$. The study concludes that the use of collector with heat pipe is more efficient than flat plate when operating as a solar water heating system.

Zhang et al [7] studied a solar thermoelectric co-generator combining heat pipes with thermoelectric modules in evacuated tube to supply electricity and heat simultaneously. They presented the system performance from experimental and theoretical point of view. The study found that the system is economical and suitable for commercial production, as the same time the payback period estimated to be about 8 years.

Nikoofard et al [8] evaluated the impact on energy consumption and greenhouse gas emissions as well as the techno-economic feasibility of solar water heating systems in Canada. The study found that the energy savings potential with solar domestic hot water systems in all provinces are similar, while the greenhouse gas emission reductions vary significantly.

Generally, in solar water heater, $10-15 \%$ of the energy is lost due to reflection, $15-20 \%$ due to re radiation, and $10-15 \%$ losses in the piping system and storage tank, thus literature giving about $50 \%$ of SWH efficiency. For $200 \mathrm{~L}$ of water with an inlet temperature of about $25^{\circ} \mathrm{C}$, to be heated to $45^{\circ} \mathrm{C}$, the energy required is $6.1 \mathrm{kWh}$. if the average solar intensity is 5 $\mathrm{kWh} / \mathrm{m}^{2}$ and the solar water heating system has an efficiency of $50 \%$, the required collector should have an area of $2.44 \mathrm{~m}^{2}$ with a tank capacity of 150 - 200 L [9].

\section{B. Electricity Consumption in Addis Ababa City}

Addis Ababa is the largest electricity consuming city in Ethiopia and is the capital, accounts $35 \%$ of the state's electricity consumption [10]. All residential customers are electrically powered homes. Water heating is the end use, accounting for $22 \%$ of the total residential consumption. Therefore, it is very important to study the alternatives for electric water heating (see table I). Consumption of electricity by water heaters directly increasing with family size, water heating appliance consumption increases more rapidly than does the consumption of another appliance. This is because hot water is used on an individual base; it cannot be shared like other appliances.

From the data, Energy consumption increases as the number of residents increases. This is clearly the case for the consumption of electricity by water heaters. With increasing family size, water heating appliance consumption increases more rapidly than does the consumption of another appliance. This is because hot water is used on an individual basis; its consumption through bulbs; TV; refrigerator etc. remains fairly constant as the household size increases. The consumption through different appliance when families size varies is presented in table II. 
TABLE I. $\quad$ END-USE ELECTRICITY CONSUMPTION IN RESIDENTIAL SECTOR IN ADDIS ABABA

\begin{tabular}{|c|c|c|c|}
\hline \multirow[b]{2}{*}{ End use } & & \multicolumn{2}{|c|}{ Monthly Consumption } \\
\hline & & $\begin{array}{c}\text { Per house hold } \\
(\mathrm{kWh})\end{array}$ & $\begin{array}{c}\text { Total household } \\
(\mathrm{GWh})\end{array}$ \\
\hline Lighting & & 41.26 & 7.19 \\
\hline Water heating & & 67.86 & 12.64 \\
\hline Air Conditioning & $\&$ & 28.53 & 4.86 \\
\hline Refrigeration & & & \\
\hline Cooking & & 57.28 & 6.93 \\
\hline Ironing & & 7.58 & 1.64 \\
\hline Other & & 20 & 4 \\
\hline Total & & 222.51 & 37.26 \\
\hline
\end{tabular}

Source: RET Energy Engineering Company Data Survey

TABLE II. EFFECT OF FAMILY SIZE ON ELECTRICITY CONSUMPTION

\begin{tabular}{|c|c|c|c|c|c|c|c|}
\hline \multirow{2}{*}{$\begin{array}{l}\text { Family } \\
\text { size }\end{array}$} & \multicolumn{7}{|c|}{ Electricity consumption through each appliance (kWh/month) } \\
\hline & Bulb & Fan & Grinder & Refrigerator & TV & Stove & Water heater \\
\hline$<3$ & 7.0 & 17.0 & 31.1 & 35.0 & 9.0 & 41.3 & 44.6 \\
\hline $3-4$ & 7.1 & 14.5 & 32.0 & 35.0 & 9.5 & 42.0 & 45.8 \\
\hline $5-6$ & 6.9 & 21.0 & 32.0 & 37.0 & 9.0 & 43.7 & 50.4 \\
\hline$>6$ & 7.5 & 19.0 & 36.0 & 36.2 & 8.8 & 51.0 & 57.6 \\
\hline
\end{tabular}

The Ethiopian electric power corporation EEPC/ELPA has almost a monopoly of electricity generation in Ethiopia, and distributed to the company, residential and any other sectors to satisfy their electric power demand, then collecting the bill monthly. According to Ethiopia Electric Agency, confirmed that the present electricity price per $\mathrm{kWh}$ is about $133.35 \mathrm{ETB}$ with annum $10 \%$ price increment.

\section{EWH Utility Data Survey from Supplier (Market)}

Storage type electrical boiler considered for comparisons because it is commonly used in Addis Ababa, from the market study Ariston, Florence \& Rheem boiler types are available, the specifications are presented in table III.

TABLE III. ELECTRICAL STORAGE TYPE BOILER AVAILABLE IN THE MARKET WITH ITS SPECIFICATION

\begin{tabular}{|llll|}
\hline Storage heater & Capacity & Watt & Cost in birr \\
\hline Ariston pro R & $501 \mathrm{tr} / 801 \mathrm{tr}$ & 1500 & $4800 / 5500$ \\
Ariston Blu R & $501 \mathrm{tr} / 801 \mathrm{tr}$ & 1500 & $3700 / 4600$ \\
Florence & $501 \mathrm{tr}$ & 1500 & 3500 \\
Rheem & $801 \mathrm{tr}$ & 3800 & 7180 \\
Ostate & $501 \mathrm{tr}$ & 2500 & 6800 \\
\hline
\end{tabular}

Source: data surveyed from market

Based on the data specification we calculate the electrical consumption and compare with SWH. The life time of an EWH is the difference between the installation and the time at which it becomes uneconomical to restore the equipment to working order because of electrical and other damages, due to corrosion, breaks in the body may lead to leakage of the water or stop heating.

\section{WORKING THEORY AND SPECIFICATION OF RET EVACUATED TUBE SWH}

Nowadays in Ethiopia not more than three company has started the technology as a business, RET energy engineering pvt. ltd. company works on importing, assembling and installation solar water heating system, utilities are manufactured in china. However, due to lack of awareness and the high upfront sale cost customers are not effectively choose the technology. The system as shown in Fig. 2 made of an evacuated tube collector, a thermally insulated horizontal storage tank with 200-liter capacity to store hot water, interconnecting pipes and circulation system, appropriate controls and accessories, an envelope and tank insulation system. In most common design to avoid the use of pump, the collector should position at lower level and the storage tank is upper position in order to allow a convective thermal loop between the exchanger of the storage tank and the evacuated tubes. Thus, when the sun radiation strikes the evacuated tubes, the density of the fluid inside becomes lower than that contained in the exchanger. The hot water collected in header from tubing goes up into the storage tank through the exchanger and heat exchange takes place then cold fluid again goes down into the lower header then into evacuated tubes [11]. 

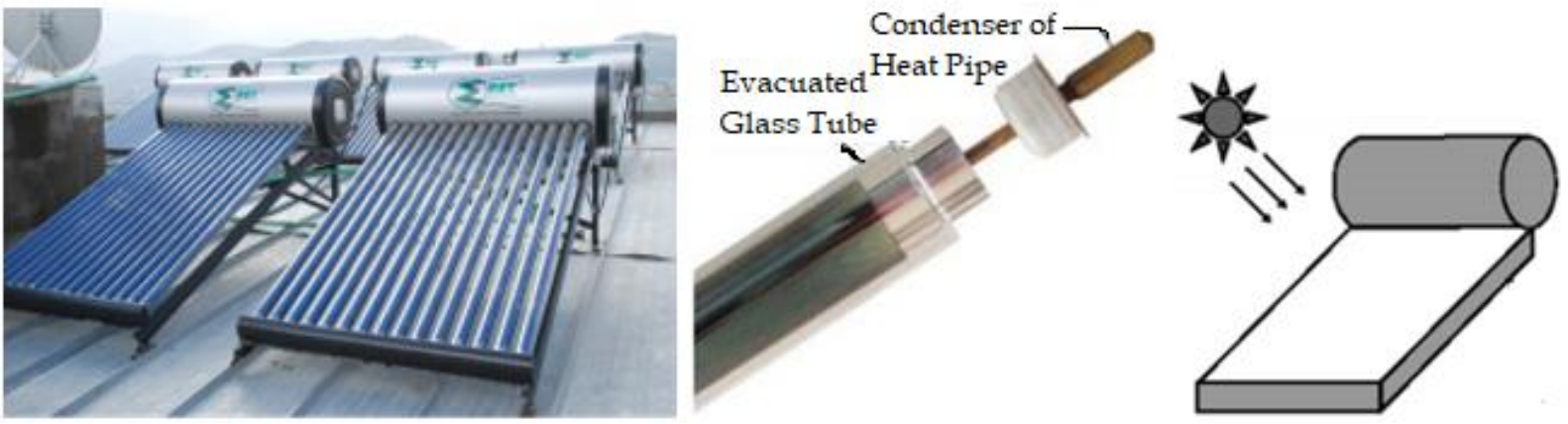

FIGURE 2. ACTUAL INSTALLATION PHOTOGRAPH AND CLOSED LOOP THERMOSYPHON RET EVACUATED TUBE SWH

The system needs $2.5 \mathrm{~m}^{2}$ space for installation and mounted on a roof or other suitable support at $45^{\circ}$ angle from the horizontal in a way that able to receive a significant amount of solar radiation. SWH is free of moving parts and requires minimal maintenance, even the maintenance depends largely on the rate of dust, corrosion or mineral deposits caused by materials dissolved in the water. The life time of a solar water heating system is the difference between the installation and the time at which it becomes uneconomical to restore the equipment to working order because of general deterioration. The failure of the system is generally due to corrosion of the copper and undetected breaks in the glass, leading to leakage of the water. Detail specification of the RET solar water heater presented in table IV based on the supplier information.

TABLE IV. SPECIFICATION OF RET EVACUATED TUBE SWH

\begin{tabular}{|llll|}
\hline SWH type & Capacity (Litter) & Initial Cost (ETB) & Life time \\
\hline Evacuated tube solar water heater & 200 & 16,250 & $20 \mathrm{yr}$. \\
\hline
\end{tabular}

Source: RET Energy Engineering Pvt, Ltd. Company

\section{MATERIALS AND METHODS}

\section{A. Solar Energy Potential in Addis Ababa-Ethiopia}

Solar energy is plenty of energy on the earth, it falls on the surface of the earth at a rate of 120 petawatts. This means all the solar energy received from the sun in one days can satisfied the whole world's demand for more than 20 years. Ethiopia experiences the tropical climatic condition. According to Tamerat [12], the country has two main distinct seasons: the rainy season (from June to August) and dry season: (from September to June) other months are the boundaries of the two seasons. The temperature throughout the year respectively range from a minimum average of $22^{\circ} \mathrm{C}$ to a maximum average of $32{ }^{\circ} \mathrm{C}$. The average experience between 7 to 9 useful sunshine hours per day and an average of 250 to 300 clear sunny days per year. Daily average solar radiation solar irradiation of about 5.68 and $6.6 \mathrm{kWh} / \mathrm{m}^{2} / \mathrm{d}$. Thus, it receives a solar irradiation of 5000 to $7000 \mathrm{kWh} / \mathrm{m}^{2}$ in a year, and has great potential for the use of solar energy and meeting the energy requirements. In the rainy season, cloud covers may affect the effective of solar energy while in hot season the extreme heat affects the efficiency. But this factor does not over shadow the benefit derived from the use of solar energy. This resource is relatively predictable and well distributed throughout the country, same as in Addis Ababa with some variations. This potential is advantageous to water heating purpose using SWH technologies, and it has the benefit of environmentally friendly that means mitigating GHG emissions associated with fossil fuel usage, and reducing peak electricity load.

\section{B. Solar Energy Potential in Addis Ababa-Ethiopia}

For SWH system, it is important to know the quantity of solar radiation energy received and distribution throughout the system, inlet collector tube temperature, the outlet collector tube temperature, the ambient temperature and the storage tank temperature. Zonen CM 10 pyrometer is used to measure solar radiation with relative error on the measuring of $\pm 2 \%$. It is connected to a numerical integrator digital display, allowing the reading of instantaneous solar power over a given period. Similarly, the temperature of outlet water is measured within 1-hour interval (see Fig. 3). The insolation increases until it reaches its maximum $(990 \mathrm{~W} / \mathrm{m} 2)$ between $12-14 \mathrm{PM}$, then it begins to decrease. This pattern is considered as the useful energy. 

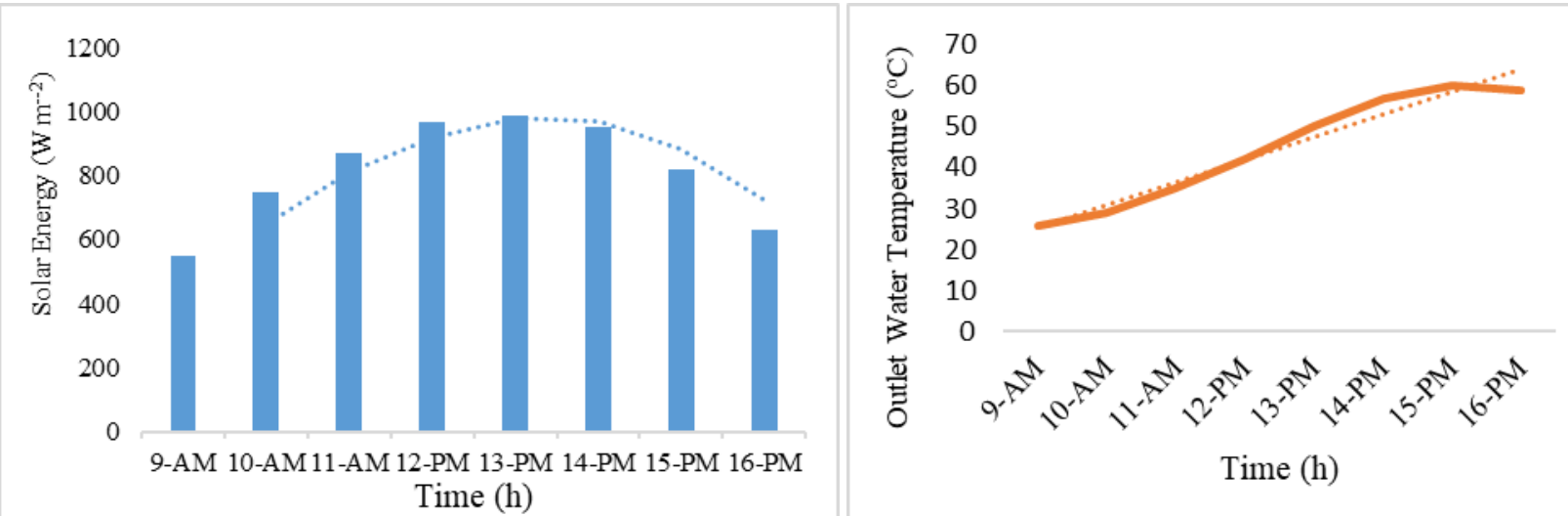

FIGURE 3. HOURLY SOLAR RADIATION AND TEMPERATURE VARIATION

It is expected, the temperature value growth with the solar intensity to reach their maxima in the middle of the day; then they drop with the global insolation falling to reach their minima at night. These result shows also that the temperature of the water in the storage tank is higher than that of the hot fluid at the collector outlet at the beginning and at the end of the day, allowing a circulation in opposite direction for thermosyphon cycle. These results show the ability of the system in providing hot water suitable for household use under such weather conditions. The storage tank water temperature reached 60 o C. (at 3-PM) before sunset, the temperature of hot water cannot rise more than this and it need long time to drop because the tank is well insulated the only loss is through piping.

\section{TECHNICAL COMPARISONS OF SWH VS EWH}

\section{A. Comparative Study}

In Ethiopia there is no local manufacturer company for SWH. There are less than three companies in this business to import and installation for local demand. Household has different alternative for water heating, in this study three water heater alternatives are presented installing SWH, using storage type electrical boiler and Using Instant water heater. The life cycle cost economic analysis for imported RET SWH versus electrical (both storage and instant) water heater are made for a system with 200 liters storage capacity.

The argument about using an electrical water heater $(\mathrm{EWH})$ or installing a solar water heater $(\mathrm{SWH})$ can never be resolved only on the basis of initial costs. A perfectly valid comparison could be made only by considering all the expenses of maintaining the two types of water heaters, one EWH and one SWH, over the same period of time and capacity. However, no such data exist in the literature. Obviously, without these data, comparisons showing the advantage of one type of water heater, leaving aside the differences in their repair, maintenance costs, etc. have little validity. Despite these limitations, it is worthwhile to compare the economic costs of the EHW and the SWH because many individuals do have the opportunity to make such a choice, and it is useful for the utilities and the planners to study these comparisons in implementing renewable energy programs.

A model for the net savings from investing in the SWH over its life time is developed here. To decide whether such an investment is economically justified, one usually compares the return on investment for a solar thermal system with those in the conventional capital market. Usually, for a return on investment analysis, a present value approach is used whereby initial investment, annual expenses and annual savings are discounted to their present value, and the sum of the first two is compared. It is, therefore, suggested to use the life cycle analysis, which reminds the user of the importance of the life time of this system when analyzing the results of the economic evaluation.

The efficiency curve of installed RET evacuated tube SWH is presented in Fig. 4. As expected, the instantaneous efficiency decreases as the ratio of temperature differences to solar insolation increases. The measurement data give an efficiency using equation (6) of $49.8 \%$ and then decreases.

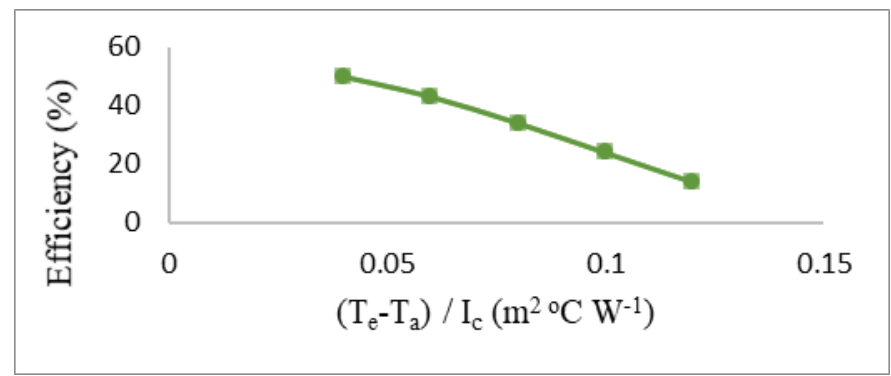

Figure 4. Instantaneous Efficiency of RET Evacuated Tube SWH

These actual installed RET evacuated tube SWH data measurement results are a very good accordance when compared to theoretical value and manufacturer set performance value.

\section{TECHNICAL COMPARISONS OF SWH VS EWH}

Consider, there are three alternatives for a customer; installing a SWH or purchasing an EWH. Then the cost comparison analysis technique is done as follows using the following mathematical modeling.

Where:

$$
\mathrm{PV}_{\mathrm{SWH}}(\mathrm{n})-\mathrm{PV}_{\mathrm{EWH}}(\mathrm{n})=\mathrm{PV}_{\mathrm{SV}}
$$

$\mathrm{PV}_{\text {SWH}}(\mathrm{n})$ : present value of installing a SWH; $\mathrm{PV}_{\mathrm{EWH}}(\mathrm{n})$ : present value of installing an EWH (either for storage or instant water heaters); $\mathrm{PV}_{\mathrm{SV}}$ : present value of savings.

The terms in the above mathematical expression are discussed detail as follows: 
$\mathrm{PV}_{\mathrm{SWH}}(\mathrm{n})=$ Initial payment + present value of sum of installments paid through the year $(n)+$ present value of maintenance, repairs, etc.

$$
=\mathrm{I}_{\mathrm{inv}}+(\mathrm{A}+\mathrm{MNT}+\mathrm{REP})(\mathrm{P} / \mathrm{A}, \mathrm{n})
$$

Where:

$\mathrm{I}_{\text {inv }}$ : Initial payment (installation cost in birr); A: Equipment cost of solar water heater; MNT: cost of maintenance (in birr); REP: cost of repairs (in birr); n: life of solar water heater (in year.); for the case of storage or instant water heaters; P/A: present value of annuity

$\mathrm{PV}_{\mathrm{EWH}}(\mathrm{n})=$ initial cost (purchase) + present value of the sum of the electricity consumption expenditure for water heating + present value of increase in the price of electricity + present value of maintenance, repairs, etc.

$$
=\mathrm{C}_{\mathrm{e}}+\left(\mathrm{E}_{\mathrm{p}}+\mathrm{INCR}+\mathrm{MNT}\right)(\mathrm{P} / \mathrm{A}, \mathrm{n})
$$

Where:

$\mathrm{C}_{\mathrm{e}}$ : purchase price of storage/instant water heaters (in birr); $\mathrm{E}_{\mathrm{p}}$ : present value of sum of electricity consumption for water heating, calculated as $\mathrm{E}_{\mathrm{C}} \mathrm{x} \mathrm{P}$; Where: $\mathrm{E}_{\mathrm{C}}$ is electricity consumption for water heating per household $(\mathrm{kWh})$, it is calculated as

$$
\mathrm{E}_{\mathrm{C}}=\mathrm{c} \times \mathrm{V} \times \Delta \mathrm{T} \times \mathrm{PR}
$$

Where:

P: electricity price $(\mathrm{ETB} / \mathrm{kWh})$; INCR: increase in the price of electricity; c: Specific heat of water, and it is: $4.187 \mathrm{~kJ} / \mathrm{kg} . \mathrm{K}$, or $1,163 \mathrm{Wh} / \mathrm{kg}^{\circ} \mathrm{C} ; \mathrm{V}$ : volume of water to be heat (in liter/day); $\Delta \mathrm{T}=\mathrm{Th}$ - Tc; Th: temperature of required hot water (in ${ }^{\circ} \mathrm{C}$ ); Tc: temperature of cold water (in ${ }^{\circ} \mathrm{C}$ ); PR: performance ratio including losses of heat through pipes and tank default value is 0.9); n: life of electrical water heater (in year); MNT: cost of maintenance (in ETB)

The thermal performance of SWH may expressed in the form of a linear performance characteristics, relating the rate of useful heat output per absorbing surface area $(\mathrm{Eu})$, the solar radiation input (Ia) and the heat losses.

$$
\mathrm{Eu}=\text { At } I a(\tau \alpha)-\text { hc At }(\mathrm{Te}-\mathrm{Ta})
$$

Where:

At: absorber tube area in $\mathrm{m}^{2}$; Te: average evacuated tube temperature in ${ }^{\circ} \mathrm{C}$; Ta: ambient temperature in ${ }^{\circ} \mathrm{C}$ ).

The instantaneous efficient $\eta$ of the SWH is defined as the ratio of useful heat gain $(\mathrm{Eu})$ delivered per absorber tube surface area to the solar radiation intensity (Ia).

$$
\eta=\mathrm{Eu} / \text { (At Ia ) }
$$

The instantaneous efficiency is influenced by several factors such as: the used materials properties, the absorber design, the weather and the operating conditions.

$$
\mathrm{Eu}=\mathrm{Fp}[\mathrm{Ia} \text { At } \mathrm{x} \tau \alpha-\mathrm{Kc} \text { At }(\mathrm{Te}-\mathrm{Ta})]
$$

Then,

$$
\eta=\mathrm{Fp} \times \tau \alpha-(\mathrm{Fp} \mathrm{Kc}(\mathrm{Te}-\mathrm{Ta})) / \mathrm{Ia}
$$

Where:

Fp: heat removal factor and the value are function of temperature $\mathrm{Te}$ used in above equation. In this study the temperature measured is the absorber's temperature. In this case $\mathrm{Fp}=1 ; \tau$ : transmittance of glazing; $\alpha$ : Collector plate absorbance.

An inclination angle will be set when the collector is installed based on the formula,

$$
\delta=23.45 \sin (360(284+\mathrm{n})) / 365
$$

A. Assumptions and Values of Variables for the Analysis

- For comparison the choice is restricted between installing RET SWH, an electrical storage type boiler and instant water heater.

- The life of RET solar water heater, electrical storage boiler and instant water heaters are taking 20, 20 and 3 years respectively, for the use of 5 family member residential.

- The maintenance cost either water heater (solar/electrical) are made simple assumption.

- Sale price of electrical storage type boiler (mostly used Ariston pro R 801tr) $=6500$ ETB

- Estimated demand for hot water is 20-30 liter per person daily.

- Cost of installing RET SWH $=16250$ ETB (considering Addis Ababa)

- Taking current Ethiopian Electric Power Corporation Electricity tariff is 133.35 ETB per $\mathrm{kWh}$ and future annum price increases by around $10 \%$ is reasonable assumption.

\section{RESULT AND DISCUSSION}

The impact of electricity consumption on the choice between RET evacuated tube solar water heater and an electrical (storage/instant) water heater is performed using engineering economics and shows that the initial cost of a solar water heater and the electricity price are the two most important parameters that used to compare those alternatives to choose. The present value of the cost of the solar water heater becomes greater than the present value of the cost of the electrical water heater and it is 29,231.27 ETB and 9,533.56032 ETB respectively. There is 19,197.70968 ETB total installation cost difference, that is the reason why home builders and commercial sectors are not interested with it. Though, in the long run, it is advantageous for the customer to use solar water heater due to power consumption. The analysis shows that with less than 6- and 14-years solar water heater is advantageous over Electrical (both storage/Instant) water heaters, it meant that the payback period of solar water heater with respective comparisons with electrical storage type and instant water heaters power consumption. The break-even analysis technique is used to study the present problem, the result presented in table $\mathrm{V}$. 
TABLE V _ WATER HEATER ALTERNATIVES BREAKEVEN CONDITION FOR COMPARISION

\begin{tabular}{|c|c|c|c|c|c|}
\hline \multirow[b]{2}{*}{ Year } & \multicolumn{3}{|c|}{ Exploitation (ETB) } & \multicolumn{2}{|c|}{ Savings (ETB) } \\
\hline & $\begin{array}{c}\text { RET Solar water heater } \\
\text { (1) }\end{array}$ & $\begin{array}{c}\text { Storage type Boiler } \\
\text { (2) }\end{array}$ & Instant Water Heater (3) & $(1-2)$ & (1-3) \\
\hline 0 & 16250 & 6500 & 1200 & 9750 & 15050 \\
\hline 2 & 16510 & 9328.12 & 3086.72 & 7181.88 & 13423.28 \\
\hline 4 & 16770 & 13156.24 & 6173.44 & 3613.76 & 10596.56 \\
\hline 6 & 17030 & 16984.36 & 8060.16 & 45.64 & 8969.84 \\
\hline 8 & 17290 & 20812.48 & 11146.88 & -3522.48 & 6143.12 \\
\hline 10 & 17550 & 24640.6 & 13033.6 & -7090.6 & 4516.4 \\
\hline 12 & 17810 & 28468.72 & 16120.32 & -10658.72 & 1689.68 \\
\hline 14 & 18070 & 32296.84 & 18007.04 & -14226.84 & 62.96 \\
\hline 16 & 18330 & 36124.96 & 19893.76 & -17794.96 & -1563.76 \\
\hline 18 & 18590 & 39953.08 & 22980.48 & -21363.08 & -4390.48 \\
\hline 20 & 18850 & 43781.2 & 24867.2 & -24931.2 & -6017.2 \\
\hline
\end{tabular}

The result where obtained by using the storage and instant electricity rates within 20 years period. The approximate unit sale value of the solar water heater is estimated to ETB 16250. According to this graph, SWH becomes more profitable than storage type boiler less than seven years and about fifteen years in comparison with the one using Instant water heater. Even one of the reasons to increases the cost of solar water heater is the initial sale cost, if the solar water sale cost reduces lifetime cost will reduce and it will be more profitable. Analysis also shows that the solar water heater needs only high initial investment and the lifetime costs does not seriously affect the average income of most Ethiopians. The advantage of solar water heater are they enables energy saving, more environment friendly than other, require less safety measures and the possibility of rural development improving. And the factors what makes the higher initial price of solar water heater are higher duties, problems of efficiency in relation with work temperature and solar water heater not manufactured locally. For these reasons, recommend to locally manufacture the solar water heater using low cost local materials and to reduce foreign currency and tax.

\section{CONCLUSION}

In the early years, many home builders and commercial business sectors choose electric water heaters because they are easy to install and relatively inexpensive to purchase. However, this study suggested that the solar water heater provides the shortest payback time and the lowest $\mathrm{kWh}$ cost compared to the two other alternatives, an average household with solar water heater can save about 1914 ETB or 1443.36 ETB per year from the cost of electricity to heat water rather than to use storage type electrical boiler or instant water heater respectively. It makes the monthly electricity bill is greater than the monthly instalment of the solar water heater less than 6 years for storage type electrical boiler and 14 years for Instant water heater. The past trends show, in Ethiopia situation there is power shortages even in capita city and the electricity tariff by itself increasing by $10 \%$ yearly. So, using of solar water heater is best alternative and attractive to save energy. The performance test presented above shows that the system efficiency meets with theoretically stated value of $50 \%$, even with the manufacturer. which hot water average temperature above $55^{\circ} \mathrm{C}$. These results prove that the system is suitable with Ethiopia weather conditions. This performance added to the relative simplicity of the system manufacturing and the absence of moving parts; makes it an interesting technological solution. The approximate unit sale value of imported solar water heater is ETB 16,250. This cost is 2 times lower than the imported ones, which shows the solar water heater is economically feasible. Finally, this study concludes that when a SWH technology replaces an electrical water heater, has benefits of improve energy security and improve energy risk management; reduce the use of electricity; reduce the national contribution to GHG emissions associated with the burning of fossil fuels, such as carbon dioxide $\left(\mathrm{Co}_{2}\right)$, Sulphur dioxide $\left(\mathrm{So}_{2}\right)$ and nitrous oxide emissions $\left(\mathrm{No}_{3}\right)$; improve the quality of life through the provision of hot water; create jobs and technology advancement in the solar energy industry; since it's free of moving parts system maintenance only depends on rate of corrosion or mineral deposit this leads very less maintenance cost. No local industry deals with the manufacturing of solar water heaters, if the system manufactured locally from locally available material and with cheap man power its lifetime cost can be reduced highly. The city administration also government of Ethiopia should support renewable energy by offering discount and long loan to households and suppliers.

\section{ACKNOWLEDGMENT}

We are grateful to Engineer Tadesse Diga, Directing Manager at RET Energy Engineering PLC for technical support and his key role to conduct the study and required data measurement on imported evacuated tube SWH. We also appreciate Bahir Dar Institute of Technology for the financial support to carry out this study.

\section{REFERENCES}

[1] B.Sudhakar Rreddy. Electrical vs solar water Heater: A case study. Energy Conversion and Management Volume 36, Issue 11, November 1995, Pages 1097-110. https://doi.org/10.1016/0196-8904(94)00084-D

[2] Karaghouli, A.A. and W.E. Alnasser. Expermental study on thermosyphone solar water heater in Bahirain. Renewable Energy Volume 24, Issues 3-4, November 2001, Pages 389-396. https://doi.org/10.1016/S0960-1481(01)00020-9

[3] A.Jamar, Z.A.A. Majid, W.H. Azmi, M. Norhafana, A.A. Razak. A review of water heating system for solar energy application. International Communications in Heat and Mass Transfer Volume 76, August 2016, Pages 178-187. https://doi.org/10.1016/j.icheatmasstransfer.2016.05.028

[4] Laborderie, Alexis \& Puech, Clement \& Adra, Nadine \& Blanc, Isabelle \& Beloin-Saint-Pierre, Didier \& Padey, Pierryves \& Payet, Jerome \& Sie, Marion \& Jacquin, Philippe. (2011). Environmental Impacts of Solar Thermal Systems with Life Cycle Assessment. World Renewable Energy Congress-Sweden. 57. http://10.3384/ecp110573678 
[5] P Veeraboina and G Yesuratnam. Optimal Design \& Analysis of Solar Water Heating System using Solar Factors for Energy Efficiency \& Thermal Performance. Universal Journal of Renewable Energy, 2014, 2, 112-125.

[6] L.M. Ayompe and A Duffy. Analysis of the Thermal Performance of a Solar Water Heating System with Flat Plate Collectors in a Temperate Climate. Applied Thermal Engineering Volume 58, Issues 1-2, September 2013, Pages 447-454. https://doi.org/10.1016/j.applthermaleng.2013.04.062

[7] Ming Zhang, Lei Miao, Yi Kang, Sakae Tanemura, Craig Fisher, Gang $\mathrm{Xu}$, Chun Li, Guang Fan. Efficient, Low-Cost Solar Thermoelectric Cogenerators Comprising Evacuated Tubular Solar Collectors and Thermoelectric Modules. Applied Energy, Applied Energy. 109. 5159. https://10.1016/j.apenergy.2013.03.008

[8] Sara Nikoofard, V. Ismet Ugursal, Ian Beausoleil-Morrison. An Investigation of the Technoeconomic Feasibility of Solar Domestic Hot Water Heating for the Canadian Housing Stock. Solar Energy, March

2014, Volume $\quad 101, \quad$ Page 308-320.
https://doi.org/10.1016/j.solener.2014.01.001

[9] Almasri, Radwan \& Almarshoud, Abdulrahman. (2017). Feasibility of Using Evacuated Tube Solar Water Heaters in Saudi Arabia. EUROPEAN JOURNAL OF ADVANCES IN ENGINEERING AND TECHNOLOGY. 2017. 232-241.

[10] Morrison, Graham, Budihardjo, I. Behnia, M.. (2004). Water-in-glass evacuated tube solar water heaters. Solar Energy. 76. 135-140. https://10.1016/j.solener.2003.07.024

[11] Tang, Runsheng \& Li, Guihua. (2017). Solar Collectors and Solar Hot Water Systems. https://10.1007/978-3-662-49088-4_31-1

[12] Tamerat Demeke Agonafer. Ventilation Performance Investigation of Roof Top Solar Chimney. American Journal of Mechanical and Industrial Engineering. Vol. 5, No. 2, 2020, pp. 15-23. https://doi:10.11648/j.ajmie.20200502.11

\section{BIOGRAPHY}

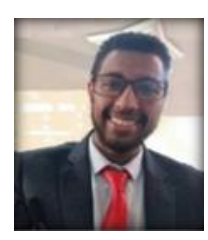

Tamerat Demeke has working experience with Bahir Dar Institute of Technology, Faculty of Mechanical and Industrial Engineering at Lecturer position. He received MSc. degree in Thermal Engineering from Bahir Dar Institute of Technology and awarded his BSc. degree from Dire Dawa Institute of Technology. He proactively participates in research activities, community service, teaching and student advising throughout his work. He has published 2 scientific papers in reputed journals, presented 5 seminars in his area. He is a reviewer in ELSEVIER (Results in Engineering). His areas of interests are Ventilation Systems, Renewable Source of Energy Systems, Combined Heating Cooling and Power Generation plant, Computational Fluid Dynamics/Heat Transfer.

Abdulbasit Nasir is working with Hawassa University, Department of Mechanical Engineering at Lecturer position. He is a PhD candidate at Addis Ababa Science and Technology University in the field of Thermal Engineering. He received MSc. degree in Thermal Engineering from Addis Ababa Institute of Technology and awarded his BSc. degree from Dire Dawa Institute of Technology. He has published 2 scientific papers in reputed journals. 